\title{
RELECTURA Y FUSIÓN DE UN MITO GRIEGO EN UN DRAMA DE HORACIO REGA MOLINA
}

\author{
RELEVANCE AND FUSION OF A GREEK MYTH \\ IN A DRAMA OF HORACIO REGA MOLINA
}

Alfredo Eduardo FRASCHINI

Universidad Nacional de Villa María (Argentina)

afraschini@gmail.com

\begin{abstract}
Resumen: En este trabajo se desarrolla un análisis comparativo del drama Polifemo y las peras del olmo, de Horacio Rega Molina, con las fuentes clásicas del mito de Polifemo: la Odisea homérica, El cíclope de Eurípides, los Idilios de Teócrito, la Eneida virgiliana, las Metamorfosis de Ovidio, y la Fábula de Polifemo y Galatea de Luis de Góngora y Argote. El autor argentino ha realizado una reescritura del mito mediante la fusión de esas fuentes literarias, y ha desarrollado la acción ubicándola en la llanura argentina en la primera mitad del siglo XX. Ha conservado los caracteres generales de los personajes centrales del mito: Polifemo, Odiseo / Ulises, y Galatea, pero ha descrito una evolución en ellos para mostrar de qué modo en la Argentina se han mezclado las razas para generar al típico criollo.
\end{abstract}

Palabras clave: mito, trasposición, oposición, campesino, urbano, autóctono, extranjero.

\begin{abstract}
This paper develops a comparative analysis of the drama Polyphemus and pears of the elm, by Horacio Rega Molina, with the classic sources of the myth of Polyphemus: the Homeric Odyssey, The Cyclops of Euripides, the Idylls of Theocritus, the Virgilian Aeneid, the Metamorphosis of Ovid, and the Fable of Polyphemus and Galatea by Luis de Góngora y Argote. The Argentine author has made a rewriting of the myth through the fusion of those literary sources and has developed the action placing it in the Argentine plain in the first half of the 20th century. He has preserved the general characteristics of the central characters of the myth: Polyphemus, Odysseus / Ulysses, and Galatea; but he has described an evolution in them to show how the races have been mixed in Argentina to generate the typical Creole.
\end{abstract}

Key words: myth, transposition, opposition, peasant, urban, autochthonous, foreigner. 


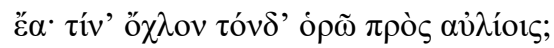

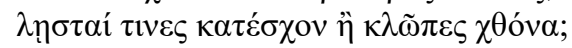

¡Eh! ¿Qué es esta multitud que veo junto a los establos? ¿Llegaron a esta tierra algunos piratas o ladrones?

Eurípides, El cíclope, 222-223.

\section{$\mathbf{P}$} alabras liminares

La recurrencia a la cultura griega — mito e historia - ha generado en la dramaturgia argentina un grupo de producciones valiosas. Desde Los reyes (1949) de Julio Cortázar, inspirada en el mito de Minotauro y ambientada en la entrada misma del laberinto cretense, hasta La oscuridad de la razón (1993) de Ricardo Monti, trasposición de las vicisitudes de la familia de Agamenón, particularmente el vínculo entre Electra y Orestes, cuyo marco histórico-social es el de Buenos Aires en la época de Juan Manuel de Rosas (primera mitad del siglo XIX), se han sucedido obras inspiradas en la historia —como Temístocles en Salamina (1949) de Román Gómez Masía y La peste viene de Melos (1956) de Osvaldo Dragún-; en la mitología pura - como Las nueve tías de Apolo de Juan Carlos Ferrari, visión humorística del vínculo entre Apolo y las Musas, y Proserpina y el extranjero (1951) de Omar del Carlo, recreación del viaje de Hércules al Infierno en un ambiente prostibulario de Buenos Aires a mediados del siglo XX - o en mitos ya elaborados por los tragediógrafos griegos — como Antígona Vélez (1950) de Leopoldo Marechal, trasposición del mito a la llamada "conquista del desierto", a fines del siglo XIX en la llanura argentina, El reñidero (1962) de Sergio De Cecco, interesante fusión de las versiones de Esquilo, Sófocles y Eurípides sobre el regreso de Agamenón y las reacciones de sus hijos, ubicada en un suburbio de Buenos Aires a principios del siglo XX, $L a$ frontera (1964) de David Cureses, inspirada en la historia de Medea y los Argonautas, ambientada en la Argentina de principios del siglo XX, y Antígona furiosa (1986), de Griselda Gambaro, aplicación del mito a la desaparición forzada de personas durante la dictadura argentina entre 1976 y 1983 - La relación entre la figura de Antígona y los vínculos de la Iglesia con una dictadura latinoamericana se desarrolla con notable originalidad en Golpes a mi puerta (1994) de Juan Carlos Gené. Se observa que estos dramaturgos que bebieron de la fuente clásica han elaborado, por lo general, su reescritura trasladando el mito en el tiempo y el espacio hacia la Argentina de los siglos XIX y XX ${ }^{1}$.

Dentro de esa línea de producción teatral se ubica Polifemo o las peras del olmo, calificada como “misterio dramático pastoril” por su autor, Horacio Rega Molina (1899-1957)², estrenada en Buenos

\footnotetext{
${ }^{1}$ Este tipo de trasposición o reescritura tiene lejanos antecedentes en las tragedias Dido y Argia de Juan Cruz Varela (1826). Son dignas de mención, en el siglo XX, además de las nombradas, La copa inhallable, de Leopoldo Lugones, La cooperativa de los Diógenes, de Velia Malchiodi Piñero, Penélope ya no teje, de Malena Sandor, Penélope aguarda, de Rodolfo Modern y Jorgelina Loubet, y Partenopeo, de César Magrini. En estas últimas el tratamiento de los mitos clásicos es más libre.

${ }^{2}$ Este escritor argentino se destacó en el campo de la poesía lírica. Su mentor y padrino fue Leopoldo Lugones, de quien heredó su tendencia estética modernista.
} 
Aires en 1945 en el histórico Teatro del Pueblo, cuya acción se desarrolla en la llanura pampeana a comienzos del siglo XX, momento en que se produce una gran ola inmigratoria, particularmente de origen europeo, hacia nuestro país.

\section{Relectura y fusión}

Es importante aclarar el sentido que estos términos adquieren en el presente trabajo. Por "reescritura" se entiende un hipertexto, esto es, una composición literaria inspirada en un hipotexto, esto es, otra del mismo género o de género diverso, en la cual se mantienen en general los lineamientos argumentales y algunos personajes, a los que se ubica en tiempos distintos y se los adapta a determinada concepción filosófica, estética o política; tarea que implica una "relectura", o interpretación renovada de las fuentes. Es lo que Genette (1989) llama "literatura en segundo grado", de la cual reconoce una enorme cantidad de variantes en lo formal y en lo ideológico. La reescritura es una forma de adaptación y decodificación. No es copiar al pie de la letra, sino apropiarse del material que se copia: el éxito de una adaptación no depende de la fidelidad al texto de partida (Stam, R. y Raengo, A., 2005: 3). Fusión es un procedimiento complejo por el cual en la reescritura se combinan, por ejemplo, distintos géneros o especies literarias (hibridación); o bien, elementos procedentes de fuentes diversas escritas u orales, o ideas que surgen de distintos modos de interpretar esas fuentes, o se transforman los caracteres de los personajes de acuerdo con las variantes que se dan en la combinación de fuentes.

En el procedimiento escriturario de Rega Molina se observan dos tipos de fusión: el de las fuentes argumentales y el de la caracterización de los personajes. La reescritura del mito hace hincapié en una doble problemática social argentina: por un lado, el enfrentamiento entre dos sectores de la población, lo que podría llamarse, en términos sarmientinos, la civilización y la barbarie ${ }^{3}$; por el otro, en la presencia de una masa notable de inmigración de distintos orígenes en la Argentina, particularmente a partir de fines del siglo XIX, fenómeno que, más allá de su influencia en el plano social y político, dio origen a una importante producción literaria ${ }^{4}$. El segundo término del título de la obra, "las peras del olmo", alude al dicho popular "pedirle peras al olmo", esto es, intentar algo imposible; el argumento, sin embargo, muestra que ese imposible puede revertirse cuando hay un verdadero acercamiento de las dos facciones que produce algo nuevo, en este caso, el hijo de Galatea y Ulises que se llamará Polifemo, suceso que no aparece en ninguna de las tradiciones vinculadas con estos personajes.

\footnotetext{
${ }^{3}$ Desde los primeros momentos de la independencia, se dieron en la Argentina procesos de enfrentamiento muy duros que tuvieron a veces resultados trágicos, y que aún hoy persisten en la sociedad argentina. "Civilización y barbarie" es el subtítulo de la obra más famosa de Domingo Faustino Sarmiento, el Facundo. La civilización, para el prócer, está formada por las personas cultas, con rasgos europeos, y la barbarie, por el gauchaje y sus violentos caudillos, a los que compara con los jefes de los pueblos nómades de África.

${ }^{4}$ El llamado "teatro de tesis", cuya manifestación más notable es la producción del dramaturgo noruego Henrik Ibsen, sirvió de modelo a autores como Florencio Sánchez y Roberto J. Payró, quienes exponen en varias de sus obras la problemática de la inmigración en la Argentina. Una visión humorística del tema aparece en el llamado "sainete porteño", con autores como Alberto Vaccarezza, Armando Discépolo y Carlos Mauricio Pacheco, entre otros. Una importante pintura de la convivencia entre argentinos y extranjeros de muy distinto origen aparece en la novela Adán Buenosayres de Leopoldo Marechal.
} 
Con respecto a las fuentes, Rega Molina fusiona en su obra dos aspectos del mito de Polifemo: por un lado, el de raíz homérica (Odisea, 9, 105-505), cuya proyección teatral se da en el drama satírico El cíclope de Eurípides, y la épica, en un episodio de la Eneida de Virgilio (3, 613-691); y por el otro, el que surge del género pastoril con Teócrito (Idilios 6 y 11), y a través de Ovidio (Metamorfosis, 13, 740-897) se proyecta hasta la célebre Fábula de Polifemo y Galatea de Luis de Góngora y Argote. El núcleo temático del primer aspecto consiste en el enfrentamiento entre Polifemo y Ulises; el segundo, en el frustrado idilio entre el cíclope y Galatea, la preferencia de la joven por Acis y la metamorfosis de este último en río ${ }^{5}$. No es improbable, por otra parte, que el autor haya conocido la comedia Polyphème de Albert Samain, y de ella haya tomado algunos elementos para la caracterización del protagonista, al quitarle rasgos de violencia y fealdad que posee en las versiones clásicas.

Estas fuentes fusionadas se combinan a su vez con elementos característicos del área rural argentina, algunos muy buenos, como la sencillez de costumbres, la idea de libertad, la cultura del trabajo y el amor a la tierra; y otros, no tanto, como ciertas supersticiones, el accionar de curanderas, los funcionarios corruptos y la policía violenta al servicio del poder de turno. El juego de oposiciones - lo rural frente a lo urbano, lo tradicional frente a lo novedoso, lo natural frente a lo industrial, la tierra ilimitada frente a la tierra parcelada, la libertad frente a la represión - simbolizado por las figuras de Ulises y Polifemo, es el eje temático que sostiene el desarrollo de la acción dramática. Pero el punto más original de la fusión reside en un intercambio parcial de características entre esas dos figuras: la personalidad de Polifemo tiene puntos de contacto con la del Odiseo homérico, y viceversa, Ulises tiene rasgos del Polifemo homérico. Todo ello envuelto en el espíritu del Polifemo pastoril de Teócrito. Estos rasgos no son un mero recurso retórico, sino que se vinculan con el desenlace de la obra, según se verá.

\section{Los hechos}

Tanto en la epopeya homérica como en el drama satírico de Eurípides, el núcleo argumental del episodio es la llegada de Odiseo al país de los cíclopes, lo que puede verse como el enfrentamiento entre dos culturas, a través de los diálogos entre Polifemo y Odiseo, en Homero, y entre Odiseo y Sileno primero y entre Odiseo y Polifemo después, en Eurípides. En uno y otro caso interviene el vino como factor que facilita el debilitamiento por embriaguez del cíclope, y la destrucción de su único ojo con una estaca afilada.

En los Idilios 6 y 11 de Teócrito, evocados luego por Ovidio y siglos después por Góngora, Polifemo se enamora de Galatea pero ella lo rechaza, y a veces ocurre lo contrario, como un apasionado juego de seducción. Ovidio (Met., 13, 750-897), inspirado casi seguramente por el ditirambo de Filoxeno de Citera conocido como Galatea o El cíclope ${ }^{6}$, agrega la figura de Acis, el bello adolescente

\footnotetext{
${ }^{5}$ Acis no figura en esta reescritura del mito.

${ }^{6}$ De esta obra han llegado hasta nosotros solamente algunos fragmentos y referencias. Francisco Rodríguez Adrados ha traducido los fragmentos de Galatea (1980: 456-457).
} 
de quien Galatea se enamora y al que Polifemo mata arrojándole un peñasco; de Ovidio lo toma Góngora (Fábula, estr. 24-63).

En el drama de Rega Molina, Ulises llega a la casa de Polifemo, hombre de campo atado a sus costumbres y habituado a la libertad que otorga una llanura sin límites. El forastero es un hombre de negocios, positivamente vinculado con el poder político y económico, que viene "a tomar posesión de estas tierras" como primer paso para "civilizar" a Polifemo y "arreglarles las cuentas al desorden, a la ignorancia y a la barbarie" (p. 45). Esa "civilización" consiste en la puesta en marcha de la última tecnología aplicada al campo, previa delimitación de la propiedad: alambrados, maquinaria agrícola, elaboración de conservas de alimentos, entre otras cosas. Novedades que el criollo interpreta como negativas. Mediante sus conexiones con el poder (el comisario, el escribano) el forastero le quita las tierras a Polifemo, seduce a la bella Galatea, la mujer que Polifemo ama profundamente, y se casa con ella. A lo largo de la obra aparecen varios personajes ajenos al mito que el dramaturgo emplea para reforzar la carga simbólica de su mensaje. Polifemo muere en el río, detalle que evoca la transformación de Acis, según la aludida tradición mítico-literaria.

\section{Los personajes}

El autor incluye veintinueve personajes en su obra, de los cuales se puede hacer una clasificación acorde con la fuerza representativa de cada uno y con las características de su desenvolvimiento en el decurso de la acción.

Los tres personajes centrales pueden considerarse arquetípicos: Polifemo, el habitante de la pampa, con sus caracteres ya mencionados; Ulises, el forastero soberbio, ávido de quedarse con los bienes del campesino; Galatea, la joven inocente, amada y admirada por Polifemo, que cae presa de los ardides del extranjero.

En un segundo plano, los personajes que encarnan un símbolo. El Poeta, que recita la Biblia y parece conocer la historia de los personajes del drama. Ulises lo detesta y llama al comisario para que lo detenga. El Comisario es el símbolo del poder al servicio de los ricos. Las personificaciones del río, la tierra y el viento simbolizan la naturaleza virgen —ámbito de Polifemo- opuesta al arsenal tecnológico que pretende imponer Ulises. En el río muere Polifemo y son la tierra y el viento los encargados de anunciar esa muerte.

Dos personajes tienen perfiles esotéricos o metafísicos: Cándida, con sus temores y presentimientos, que es algo así como la voz del pueblo y de la conciencia colectiva del mundo rural, y el linyera, un vagabundo en quien Galatea cree reconocer la imagen de Polifemo, un desconocido que parece tener conciencia de lo que ocurre, pero no lo revela. Aquella actúa como trasposición del coro trágico griego; el linyera, como un Tiresias parco y misterioso.

Hacia el final de la obra Cándida entona una antífona sobre el nacimiento del hijo de Galatea en la que los personajes presentes en la escena actúan como coro. Aquí hay un reflejo de cristianismo que se extiende y amplía hasta el final de la obra. Polifemo renace "en la tierra de su amor y su dolor", y 
como un Cristo gaucho "volverá sobre la tierra y bajará a la tierra y así por los días de los días y por los siglos de los siglos” (p. 133). Esa resurrección corresponderá siempre a una renovación de los valores tradicionales a través de las futuras generaciones.

Tanto en las fuentes clásicas como en la obra de Rega Molina los caracteres físicos y espirituales de los personajes principales aparecen en boca de otros personajes tanto los vinculados con la acción como los ajenos a la misma. En Homero, en boca de Odiseo; en Eurípides, en boca de Odiseo, de Sileno y del mismo Polifemo; en Teócrito, en boca de los pastores Dafnis y Dametas (Idilio 6), en boca del relator y de Polifemo, cuando aquel reproduce el canto del cíclope (Idilio 11). En Virgilio (Eneida, 3, 613-691) es Aqueménides el que cuenta la aventura que le tocó vivir en la tierra de los cíclopes como compañero de Ulises. En Ovidio es Galatea la que narra su propia historia y describe a los personajes de la misma. En Polifemo o las peras del olmo esos caracteres están en boca cuatro personajes: Ulises, Polifemo, Galatea y Hada.

Homero y Eurípides, y por tradición, Virgilio y Ovidio, presentan un Polifemo cargado de elementos negativos. Odiseo, en el noveno canto de la Odisea, al narrar su aventura a Alcinoo, dice

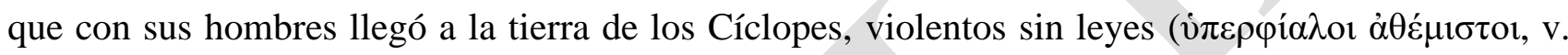
106), que no siembran la tierra, no tienen asamblea ni sistema de administración de justicia, no tienen naves, viven en grutas, en la montaña, ocupados solamente de sus familias; esto es, de manera opuesta al modelo griego de la $\pi$ ó $1 \varsigma$ (vv. 105-115). Cuando a lo lejos ve a Polifemo lo describe como un varón

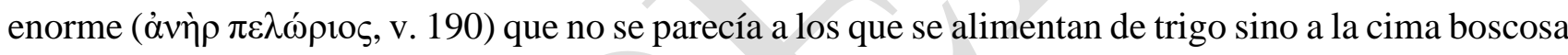
de los montes. Agrega luego que los cíclopes no respetan a los dioses porque se consideran superiores a ellos, y que practican el canibalismo (vv. 275 ss.). En el drama satírico de Eurípides, Sileno

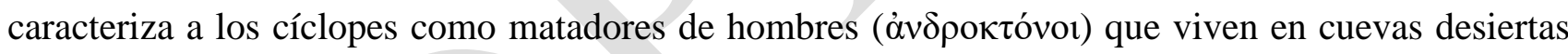

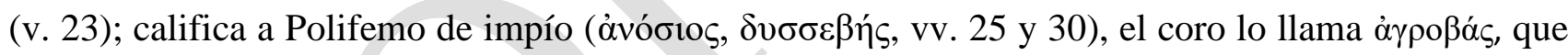

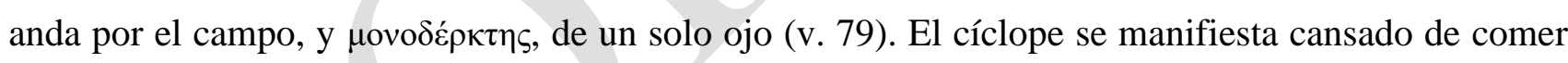
carne de animales y desea degustar la carne humana (vv. 247-249). Con respecto al modo de vida de los cíclopes, Sileno reitera algunos puntos de la tradición homérica y agrega otros: habitan en cavernas, ninguno obedece a otro, son pastores, se alimentan de queso y carne de ganado, no conocen el vino, no bailan, no son hospitalarios y practican el canibalismo (vv. 90-93). Virgilio los califica de infandi (malditos, innombrables) y vasti (enormes) (vv. 643 y 647), y a Polifemo, arduus (de gran altura), que alcanza a tocar los astros, y que para nadie resulta visu facilis nec dictu adfabilis (fácil de mirarlo ni dispuesto a hablarle) (vv. 619-621), en el relato de Aqueménides, que consigna también el hábito de consumir carne humana.

El Polifemo de Teócrito es poderoso en bienes y eximio flautista. Galatea, en su juego de seducción, lo califica de pastor intratable y amante insensible (6, 6-7), No es del todo feo: su ojo es reluciente, su barba, varonil, sus dientes, blancos como el mármol de Paros, y los sones de su flauta

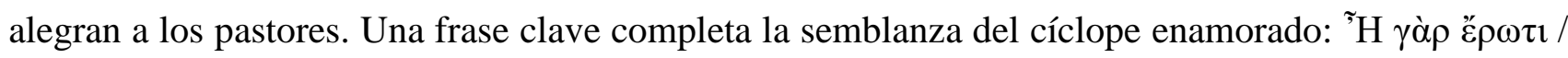

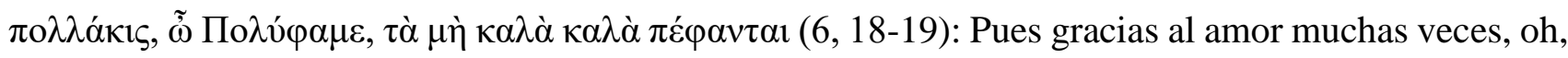
Polifemo, las cosas no bellas se muestran bellas. En el Idilio 11 el cíclope traza un autorretrato: tiene 
una sola ceja hirsuta de oreja a oreja, un solo ojo, un hocico feo y chato, y es peludo, pero es el mejor en tocar la siringa, y además es poseedor de animales, leche, queso en cantidad, y en su cueva hay todo tipo de plantas y frutos, agua fresca y leña para el fuego (vv. 38-48). Una imagen del locus amoenus que abunda en poetas de temática bucólica.

Ovidio carga a Polifemo de calificaciones negativas; primero, relativas a su personalidad: inmitis, duro, cruel, horrendus, que causa horror, visus ab hospite nullo inpune, por ningún huésped visto impunemente, dis contemptor, despreciador de los dioses (vv. 759-761); luego, en boca del mismo Polifemo, como una suerte de autorretrato ${ }^{7}$, a su inmensa figura casi monstruosa: quantus (cuán grande), cuerpo no menor que el de Júpiter, coma plurima (abundante cabellera) que sombrea como un bosque, cuerpo peludo, como erizado de saetas, barba varonil, un único ojo en mitad de la frente, a manera de gran escudo (vv. 840-852). Coincide con las fuentes griegas en su condición de pastor y de flautista, y en las características de su hábitat y de su provisión de bienes y alimentos.

Góngora sigue a Ovidio y llama a Polifemo "horror de aquella sierra", "monte de miembros", de un solo ojo, que tiene un pino como bastón o cayado, de negro y abundante cabello, barba impetuosa que cubre su pecho, y piel manchada (estr. 6-9). Agrega que toca una flauta de cien cañas con la que produce un bárbaro ruido (estr. 12). En su canto a Galatea, Polifemo se presenta como un pastor rico, y menciona los mismos bienes que se declaran en todas las fuentes grecolatinas (estr. 49-52).

El Polifemo de Rega Molina posee algunas características comunes de las versiones clásicas, si bien en líneas generales está más cerca del de Teócrito: su apego a la tierra, su alimentación, su condición de campesino que vive en un lugar sencillo, de algún modo aislado del trajinar mundano ${ }^{8}$, su afición a la música y el canto. Un punto de fusión interesante es el hecho de que el autor traslada caracteres del personaje de fuente pastoril al de fuente homérica. En la primera escena del acto primero así lo pinta el diálogo entre Ulises y Polifemo:

ULISES. Dicen que gustas de la vida pastoral, del cuidado de vacas y ovejas; que conoces las virtudes de la naturaleza; que compones canciones...

POLIFEMO. Todas ellas para Galatea... Además, puedo decir cuándo va a llover; si cambiará el viento; de qué lobo es el pelo encontrado en las matas (p. 9).

En el mismo acto, Ulises agrega un elemento que evoca a la figura homérica del cíclope: su fuerza y su resistencia, y ciertos rasgos de bestialidad ${ }^{9}$.

ULISES. Eres un niño grande, lo que se llama un niño grande, mi buen pastor, y además, labriego ${ }^{10}$. Oí decir que eres capaz de hachar un monte, tú solo, de hacer, en fin, los trabajos de Hércules ${ }^{11}$. [...] Dientes de lobo. [...] Sus manos...pelos ... callos ... una maza de carne (pp. 19-24).

\footnotetext{
${ }^{7}$ Este recurso, por el cual Polifemo se contempla a sí mismo en el reflejo del agua, aparece en Teócrito, Id., 6, 35-38.

${ }^{8}$ En algunos aspectos, su personalidad coincide con la idea horaciana sobre la vida alejada de los negocios (Epodo II), heredada de la $\alpha$ $\tau \rho \alpha \hat{\xi i ́ \alpha}$ epicúrea.

${ }^{9}$ La fealdad de Polifemo, que se describe con crudeza en Homero y en Eurípides, no es un factor que se señale en la obra de Rega Molina. En ese sentido, sigue más la línea de Teócrito.

${ }^{10}$ Este detalle es interesante, porque tanto en Homero como en Eurípides el cíclope es pastor, pero no cultiva, porque la naturaleza le ofrece todo. El trabajo del gaucho argentino incluye por lo general la agricultura y la ganadería.

${ }^{11} \mathrm{El}$ autor, al mencionar a Hércules, deja entrever el vínculo mítico del personaje.
} 
Hada, una mezcla de Nausicaa, Circe y Calipso del mito homérico, y por momentos una suerte de sibila omnisciente, dirigiéndose a Polifemo y a Ulises, amplía el retrato de aquel, señalando diferencias con el forastero.

HADA. No te aflijas, Polifemo, no importa que Ulises te deje ciego y sin lazarillo. Tú eres hermoso, fuerte, bien plantado. Hueles a romero, a tomillo, a hierbas húmedas y no a lociones como Ulises. Desde aquí escucho la respiración de tu pecho, y es lenta y honda, como el ruido del mar. Y tú, Ulises, tú haces el ruido de la bronquitis crónica (p. 23).

La que da Galatea es una semblanza de orden espiritual.

GALATEA. Si por él fuera, se cubriría con una piel de tigre. Le ha hecho la cruz a lo que hay más allá de sus tierras; y dentro de ellas bien poco que hay, ¿no es así? A veces andamos, andamos, y al cabo de mi cansancio suele decirme: "hasta acá llega lo mío". Yo no veo ninguna marca pero estoy segura de que no se equivoca (p. 33).

Con respecto a la figura de Odiseo / Ulises, en la tradición clásica tiene características que, desde el punto de vista griego (Homero, Eurípides), son positivas; pero no lo son tanto según el criterio latino

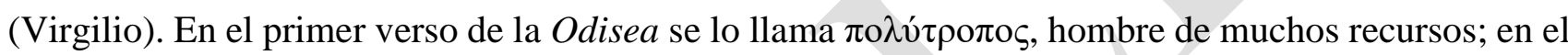
primer verso del canto noveno, $\pi \circ \lambda u ́ \mu \eta \tau \iota \varsigma$, ingenioso, astuto; en otros pasajes de la epopeya aparecen epítetos como $\alpha \dot{v} \tau i ́ \theta \varepsilon \circ \varsigma$, divino $(1,70), \pi \circ \lambda v ́ \tau \lambda \alpha \varsigma$, paciente $(5,171), \tau \alpha \lambda \alpha \sigma i ́ \varphi \rho \omega v$, de espíritu paciente,

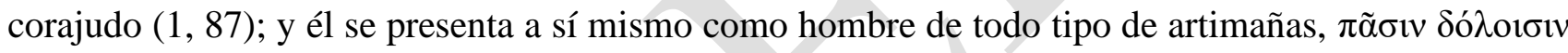
$(9,19-20)$.

En Eurípides, el primer epíteto de Odiseo lo da Sileno: $\kappa \rho$ $\tau \alpha \lambda$ ov $\delta \rho \mu v ́$, aguda castañuela, esto es, parlanchín (v. 104), que el griego interpreta como insulto. o simplemente lo llama $\xi \dot{\varepsilon} v o \zeta$, forastero (v. 102). Odiseo se encarga de mostrarse con aspectos favorables: ha participado en la destrucción de Troya, pertenece a una raza que valora en gran medida la hospitalidad, se muestra piadoso frente a los dioses. Virgilio, en cambio, subraya los rasgos negativos del personaje: durus, duro $(2,7)$, pellax, mentiroso, pérfido $(2,90)$, scelerum inventor, inventor de crímenes $(2,164)$, dirus, destructor $(2,261)$, saevus, cruel $(3,273)$, infelix, infeliz, insatisfecho $(3,613)$.

El Ulises de Rega Molina es un forastero cuya finalidad, casi obsesiva, es apropiarse de las tierras de Polifemo y desde las primeras escenas muestra aspectos de una modernidad que choca con el espíritu tradicionalista del criollo. Habla de la leche en polvo o condensada, de la carne envasada, de la música que puede escucharse a través de un disco, de un juguete mecánico que aparenta ser un corderito, del insecticida que puede fabricarse con flores, de un aparato para pelar las papas, de los elementos desechables y reemplazables, de la fotografía, y de las armas que sirven para matar desde lejos.

En una escena representada por cuatro personajes - Polifemo, Galatea, Hada y Ulises - se perfilan las ideas opuestas que el criollo y el forastero tienen sobre la tierra (pp. 36-39). Ulises habla de títulos de propiedad, de alambrados, señales, bebederos y cerrojos, y muestra un plano en el que 
están representados los accidentes geográficos y los límites de los campos. Polifemo habla de la tierra que heredó de sus padres y en la que están enterrados los huesos de sus abuelos.

POLIFEMO. (La tierra es) ... Del que cuenta su historia con la historia de los animales, de los árboles, de las piedras. Esta heredad es nuestra, porque con esa idea crecimos y nos formamos sin que nadie, hasta ahora, viniera a decirnos: "no, no es vuestra, es nuestra". [...] Mi heredad me da lo que yo le pido con mi trabajo. Y nada más. Mire por sí, don Ulises, y déjeme mirar por mí, que es de hormigas andar muchas por la misma senda y es de lobos andar cada uno por su senda. [...] Abrirá usted anchos caminos, pero la dividirá en cuadros; los trigales crecerán. Y usted, el primero, comerá ese trigo convertido en pan, sin valor para echarlo de su boca apenas piense lo que ese pan lleva en su miga: el cansancio de muchos huesos, el dolor de muchas almas (pp. 6667).

El autor destaca aquí el carácter materialista, utilitario y mercantilista de Ulises, que de algún modo se corresponde con el comportamiento de Odiseo en el drama de Eurípides, cuando pretende negociar el pedido de víveres.

Es evidente que las diferencias entre ambos personajes se acentúan mediante un juego de contrastes: lo moderno frente a lo tradicional, lo artificial frente a lo natural, el interés mercantil frente a la generosidad, el escenario natural transformado en fuente productiva, la libertad de recorrer el campo frente a la demarcación y los títulos de propiedad. Pero el punto más importante, por su profundidad, es el concepto de vida y de riqueza que cada uno expone, y que Rega Molina elabora a partir de los caracteres que uno y otro personaje manifiestan en las diversas fuentes.

ULISES. La civilización moderna, esa de la que tú tienes las primeras noticias, las primeras pruebas, tiene un lema secreto: insistir. La vida actual se basa en la insistencia, no en la existencia. [...] El $\mathrm{ABC}$ del rico o del que llega a rico es tener idea de la pobreza. Es el punto de partida, porque desde ese momento sabe lo que tiene que vencer; de lo que tiene que triunfar. Y tú no tienes ideas al respecto, es decir, no tienes ambiciones (pp. 11 y 22).

POLIFEMO. Antes de ayer Ulises, ese forastero, me dijo, apenas supo quién era yo, que mi vida ya no es vida. Y me lo dijo cuando yo estaba sintiendo en mí, a mi alrededor, toda la fuerza, toda la llama de la vida. La verdadera diferencia entre Ulises y yo no está en nuestras vidas, sino en lo que queremos de la vida y en lo que pensamos de la muerte. Se vive, conforme se piensa de la muerte. Y yo creo que hay una gran diferencia entre la vida y la muerte, como lo han de creer el caballo y la vaca. Ninguna hormiga se afana, trabaja y ahorra y junta como para mil años. Ulises es la hormiga que cree que nunca morirá (p. 63).

El mencionado juego de oposiciones que emplea Rega Molina para caracterizar a estos dos personajes conserva el sentido agónico de los diálogos entre Odiseo y Polifemo tanto en Homero como en Eurípides. Sobre este último caso, Sánchez (2004) señala que en el "agón” entre Odiseo y Polifemo, en el drama satírico de Eurípides, se observa la dinámica de oposiciones entre lo elevado y lo monstruoso, traducido en un choque de valores particulares que cada personaje pretende transformar en universales, lo que, más allá del efecto cómico que puede producir en el espectador, abre una zona textual dedicada al debate filosófico. 
En cuanto a Galatea, ella es figura central en Teócrito, y las características físicas y espirituales que le atribuye el siracusano se repiten en Ovidio y en Góngora ${ }^{12}$. En el sexto Idilio se manifiesta caprichosa, juguetona, dedicada a un juego de seducción que consiste, sobre todo, en molestar a Polifemo. Y en el undécimo aparece, en boca de Polifemo, el retrato físico que inspirará a los otros poetas: $\lambda \varepsilon v \kappa \alpha ̀ ~ \Gamma \alpha \lambda \alpha ́ \tau \varepsilon 1 \alpha$, blanca Galatea; $\lambda \varepsilon v \kappa о \tau \varepsilon ́ \rho \alpha ~ \pi \alpha \kappa \tau \tilde{\alpha} s$, más blanca que la leche cuajada;

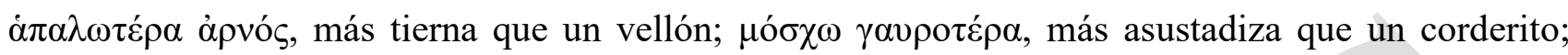

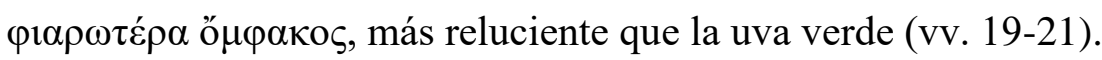

Ovidio amplía notablemente las cualidades de la belleza de Galatea, también en boca de Polifemo: Candidior folio nivei ligustri, más blanca que la hoja del níveo ligustro, floridior pratis, más florida que los prados, splendidior vitro, más reluciente que el cristal, aestiva gratior umbra, más grata que la sombra estival, mobilior damma, más inquieta que el gamo, lucidior glacie, más luminosa que el hielo, matura dulcior uva, más dulce que uva madura, mollior cycni plumis, más blanda que las plumas del cisne. Pero agrega aquellas de su carácter que hacen sufrir al cíclope: saevior indomitis iuvencis, más cruel que los potrillos no domados, durior annosa quercu, más dura que la encina vieja, fallacior undis, más engañosa que las olas, violentior amne, más violenta que el río, acrior igni, más ardiente que el fuego, asperior tribulis, más áspera que los rastrojos, feta truculentior ursa, más terrible que osa recién parida, ventis volucrique fugacior aura, más huidiza que los vientos y la brisa volátil $(13,789-807)$.

El retrato de la Galatea de Rega Molina se da través de varios personajes.

POLIFEMO. Horas enteras me paso mirándola, y no sabría, ahora, decirle cómo es. ¿No dije ya que los pájaros la saludan, al verla? Y es tan ligera que la hierba que ella pisa vuelve a enderezarse. [...] Canta a su modo. Y corre, como los arroyos. [...] Siempre se ata el pelo con un vivo de margaritas silvestres. [...] Y hallando agua clara se mira en ella, hace muecas, dice locuras y ríe (pp. 19-20).

HADA. (A Galatea). Eres más fresca y hermosa que las margaritas que traes prendidas en los cabellos (p. 32).

CURANDERA. Galatea es ansina, como las ovejas, de andar por medio del campo, poco por los caminos. [...] Una campesina de veras (pp. 57-58).

POLIFEMO. Ya quedan pocas como ella. [...] Nunca le pasa nada. [...] Soy feliz con ella... Somos felices (p. 58).

Las comparaciones relativas a la belleza de Galatea se desarrollan en el campo de la naturaleza, tal como se da en las fuentes clásicas. Ulises, en cambio, según la visión de Hada, parece dejar de lado los elementos naturales en la consideración de las cualidades de la joven, y prefiere otros, artificiales, con el pretexto de formar una belleza a su gusto.

HADA (Imitando un diálogo entre Ulises y Galatea). “Galatea, cuán distinta eres de las mujeres que he conocido. Tu piel huele a manzanas, pero podría oler a una destilada esencia de violetas. Tu mano, oh, tu mano es pequeña, pero yo le haré quitar parte de su sangre para que languidezca e

\footnotetext{
${ }^{12}$ Galatea es personaje femenino principal en la Bucólica primera de Virgilio y en la primera Égloga de Garcilaso de la Vega, y sus características son las que parten de Teócrito.
} 
imite al marfil. Los ungüentos prestarán a tu piel la transparencia que el sol le ha robado. Y te bañarás en leche.” “¿En leche?” "Sí, como Cleopatra.” “Y para qué?” "Para los placeres, para la dicha." "No me hables así, Ulises. Soy una aldeana. Déjame con mi aldeanía.” [...] (p. 70).

Galatea ama a Polifemo, pero se casa con Ulises. La presencia del forastero ha provocado en ella una transformación. Ella también es parte de aquello de lo que Ulises viene a apoderarse; de allí su miedo y su alejamiento de la naturaleza, como manifiesta en un largo monólogo cercano al final de la obra. En ese monólogo evoca también la última percepción visual y auditiva (la melodía de la flauta) de Polifemo, en el río.

GALATEA. Las paredes me aprietan la piel, pesan sobre mis huesos, se desmoronan sobre mis carnes. Quiero mirar las nubes, el horizonte. Hasta me animaría a llegarme al río, inclinarme, estirar el brazo y meterlo en el agua. Antes lo hacía siempre y me parecía que yo misma formaba parte del río. [...] Hace más de un año que no me acerco a sus orillas, que no meto mis pies descalzos en el fango. [...] Y fui al río con ese, con Ulises. Y desde el río volví a oír los sones de su flauta. [...] Y vi a Polifemo, nadando. [...] No sé si puede hacerse, pero yo lo vi. Que me desmienta el río (pp. 107-108).

En la tradición clásica Galatea se enamora de un joven bellísimo, Acis, que físicamente es la contrafigura de Polifemo. En la presente obra ella se casa con Ulises, contrafigura moral de Polifemo, al que no ama. Es víctima de una seducción casi demoníaca, que la arrastra fuera de su propia identidad.

\section{El marco escénico}

Hemos visto que el hábitat de Polifemo, en todas las fuentes, es una cueva llena de alimentos, en un campo donde abundan el ganado y los frutos. Importa señalar que sus alimentos básicos son el queso y la leche, y lo que trae Odiseo / Ulises es un elemento nuevo, el vino.

Frente a la idea de una pampa sin límites, en el drama de Rega Molina los elementos de medición y demarcación (teodolitos, alambrados, palos) adquieren carácter simbólico de límite, de manera análoga a los certificados de propiedad de los que Polifemo carece y Ulises valora en grado sumo. El arma con la que Ulises mata al pájaro que anuncia la llegada de Galatea, al comienzo de la obra, es un símbolo de la fuerza irracional y de la destrucción de la belleza y de los sentimientos mediante la violencia.

Las innovaciones que impone Ulises al hacerse dueño de las tierras de Polifemo conforman una violenta ruptura de costumbres que, hasta ese momento, encarnan elementos esenciales de la vida del criollo de campo: corta los sauces porque traen moscas; prohíbe hacer compras en la pulpería; rechaza el modo de ordeñar de los peones; implanta el mate cocido porque le molesta el ruido del mate con bombilla; da por terminados los cuentos de aparecidos, los velorios con baile y la práctica de curanderismo; echa a los perros; saca del medio a los antiguos pobladores y toma peones gringos. 


\section{Sentido alegórico de la obra}

En la fuente homérica, Ulises representa la civilización griega que acaba de vencer a los troyanos, y Polifemo la monstruosidad de lo desconocido a lo que hay que destruir o limitar. El vino es un medio para debilitar al cíclope y quebrarlo. En la fuente pastoril, la fealdad de Polifemo contrasta con la belleza de Galatea; pero el cíclope se manifiesta a través de una forma bella, la música y el canto, en tanto ella lo desdeña y prefiere a alguien que es bello y que finalmente se transforma en río.

La suma de arquetipos y símbolos y la fusión de las vertientes del mito configuran una alegoría de la invasión de determinados valores en una persona o en una sociedad "inocente", con el pretexto de mejorarla ${ }^{13}$. Esa invasión, resistida al comienzo, termina por generar una identidad que no reniega de sus valores primitivos y acepta, de los nuevos, aquellos que no la deterioran.

La antífona que cantan Cándida y el coro prefigura un retrato del futuro habitante de las pampas resultante de la fusión del criollo con el forastero.

CÁNDIDA. Si cabe elección, / yo oí su pedido: / lo quiere nacido, / nacido varón. / Varón de a caballo, / de fina cintura, / la mano segura, / el ojo de gallo. / Guapo en la guapeza, / en la honra, honrado. / Varón bien probado / de pies a cabeza (pp. 125-126).

A su vez, el hecho de que el hijo de Galatea y Ulises se llame Polifemo es un dato que sintetiza esta idea. Es ella la que confronta en el hijo los caracteres de uno y otro:

GALATEA. Yo me voy, y él queda como simiente viva que fue y será, para que en estos mismos campos y no en otros siga viviendo y se enseñoree la estampa de Polifemo. [...] ¡Míralo bien! ¡Pésalo en tus brazos! ¡Arrima tu cara a su rostro! ¡Tómale el aliento! ¡Y verás que es Polifemo; de su raza y de mi sangre; y a medida que crezca será más él y menos tú! Y te sobrevivirá con su amor a la tierra, con su simplicidad, con su pureza de labriego y de pastor (pp. 131-132).

Como en La gringa de Florencio Sánchez, en los sainetes de Armando Discépolo, particularmente en Mustafá, y en la novela Adán Buenosayres de Leopoldo Marechal, el hombre nuevo se plasmará con la fusión de sangres de diverso origen en un suelo cuya desmesura geográfica permite abrir caminos hacia el futuro, siempre que medie el amor en ese proceso ${ }^{14}$.

\section{Palabras finales}

Un viejo argumento proverbial dice que, así como los mexicanos descienden de los aztecas y los peruanos, de los incas, "los argentinos descienden de los barcos", en alusión a la mezcla étnica de origen extra-americano que los caracteriza. Durante la conquista muchos españoles tuvieron hijos con

\footnotetext{
${ }^{13}$ El término "inocente" que aquí se aplica pertenece al filólogo Richard Moorton (1989: 105ss.), quien analiza el mito de Eneas y la guerra que su presencia genera en los pueblos del Lacio y alrededores (cantos 7 a 12 de la Eneida); para él, los pueblos itálicos se defienden de una invasión extranjera, son "inocentes" en la medida en que desean permanecer en su estado cultural y no permitir la intromisión de un grupo capitaneado por un troyano.

${ }^{14}$ En el drama de Sánchez la fusión étnica se da entre criollos e italianos; en el sainete de Discépolo y De Rosa, entre criollos, italianos y "turcos" (así se los llamaba, en general, a los procedentes de los países árabes); en la novela de Marechal aparecen todas las etnias que hacia 1920 habitaban en las viviendas colectivas (conventillos) de Buenos Aires, cuyos descendientes se fusionaban en una nueva raza criolla.
} 
mujeres de los pueblos originarios. Es probable que esos hijos sean los primeros "gauchos"15. A principios del siglo XIX llegan ingleses, franceses e italianos; y a partir de 1880, alemanes, polacos, rusos, árabes, africanos y japoneses. El mayor crisol de razas se gestó en la llamada "pampa húmeda" (Buenos Aires, Santa Fe, Córdoba). De allí el valor alegórico que tiene esta obra de Rega Molina, sobre todo porque el año de su estreno es el de la finalización de la Segunda Guerra Mundial, hecho que provoca también una oleada inmigratoria notable.

Ulises no tiene nacionalidad definida en el texto, y representa a un tipo de inmigrante distinto del que llega empobrecido, como aquellos de principios del siglo XX. Hay en su figura ciertos rasgos del invasor capitalista, de aspecto técnico-científico, particularmente inglés o norteamericano, que abundó en los países latinoamericanos a lo largo de todo el siglo, con distintos matices.

El texto de Rega Molina nos permite, según mi opinión, reflexionar brevemente sobre la invasión cultural que se cierne sobre nosotros en nuestros días y la supuesta inocencia de quienes la padecemos. Una invasión que, con pretextos tecnológicos y apelaciones hedonísticas mucho más zafadas que el tramposo vino de la Odisea, actúa sobre la memoria, exalta lo instantáneo (para desecharlo inmediatamente), reniega del pasado y lo desconoce, y plantea una suerte de futuro virtual tecnificado y consumista, en el que poco espacio ocupen la tradición, la discusión, el pensamiento y la voluntad.

En ese universo del olvido están ocultos nuestros poetas, nuestros pensadores, nuestros pintores y escultores, nuestros científicos, nuestro teatro, nuestra música. Y es importante insistir en los posesivos porque, como el Polifemo de Rega Molina, todos somos dueños de esa cultura enorme y rica sin exhibir títulos de propiedad. Es inútil, si no imposible, comprender el presente sin conocer el pasado; no podemos planificar el futuro sin saber quiénes somos, qué sentimos, qué necesitamos, qué objetivos nos proponemos. Esperemos que los Ulises que diariamente llaman a nuestra puerta y se meten en nuestras casas no se lleven todo lo que legítimamente nos pertenece y que su accionar no esterilice la posibilidad de nacimiento de renovados Polifemos.

\section{Bibliografía}

CONCOLORCORVo (1942). El lazarillo de ciegos caminantes. Buenos Aires: Solar.

CORTÁZAR, J. (1949). Los reyes. Buenos Aires: Sudamericana.

CURESES, D. (1955). La frontera. Buenos Aires: Carro de Tespis.

DE CECCO, S. (1979). El reñidero. Buenos Aires: Huemul.

Del CARLO, O. (1958). Proserpina y el extranjero. Buenos Aires: Nova.

DiscéPolo, A. y De RosA, R. (1921). Mustafá. Buenos Aires: Bambalinas.

Dragún, O. (1956). La peste viene de Melos. Buenos Aires: Ariadna.

EURÍPIDES (2013). Cyclops, and major fragments of Greek satyric drama. Oxford: Oxbow books.

FERRARI, J. C. (1983). Las nueve tías de Apolo. Buenos Aires: Colihue.

\footnotetext{
${ }^{15} \mathrm{El}$ origen del gaucho es tema discutido por historiadores y antropólogos. Su figura, bajo el nombre de "gauderio", aparece en El lazarillo de ciegos caminantes de Concolorcorvo (1773) con las características típicas que se atribuyen en textos y testimonios posteriores. Alrededor de su figura se desarrolló una literatura llamada precisamente "gauchesca".
} 
Gambaro, G. (1989). Antígona furiosa. Buenos Aires: Teatro 3.

GENÉ, J. C. (1988). Golpes a mi puerta. Buenos Aires: Torres Agüero.

Genette, G. (1989). Palimpsestos. La literatura en segundo grado. Madrid: Taurus.

Gómez Masía, R. (1968). Temístocles en Salamina. Buenos Aires: C.E.A.L.,

GóngORA Y ARGOTE, L. (2012) Fábula de Polifemo y Galatea. Sevilla: Facediciones.

HOMERI (1961). Odyssia. Oxford: Clarendon Press.

MAREChAL, L. (1966). Adán Buenosayres. Buenos Aires: Sudamericana.

Marechal, L. (1972). Antígona Vélez. Buenos Aires: Citerea.

MonTI, R. (1993). La oscuridad de la razón. Buenos Aires: Corregidor.

Moorton, R. (1989). The Innocence of Italy in Vergil's Aeneid. American Journal of Philology.

Baltimore: J. Hopkins University, 110, 105-130.

OvidIO (2019). Metamorfosis. Madrid: C.S.I.C., colección Alma mater, tomo III. Edición de Bartolomé Segura Ramos.

Rega Molina, H. (1945). Polifemo o las peras del olmo. Buenos Aires: Poseidón.

STAM, R. y RAENGO, A. (eds.) (2005) Literature and Film (A Guide to the Theory and Practice of Film Adaptation). Malden: Blackwell Publishing.

RODRÍGUEZ ADRADOS, F. (1980). Lírica griega arcaica (poemas corales y monódicos, 700-300 a.C.). Madrid: Gredos.

Samain, A. (1921). Polyphème. Paris: Albert Messein éditeur,

SÁnCHEZ, F. (1997). La gringa. Buenos Aires: Colihue.

SÁNCHEZ, L. A. (2004). "Humor y dialéctica del contraste en el episodio primero de El Cíclope de Eurípides". Stylos. Buenos Aires: U.C.A. 13, 119-131.

SARMIENTO, D. F. (2000). Facundo. Buenos Aires: Colihue.

THEOCRITUS, Eidyllia. Recuperado el 23 de marzo de 2019 de http://www.mikrosapoplous.gr/.

VIRGILIO (2004). Bucólicas. Buenos Aires: Losada. Introducción, traducción y notas de Pablo Ingberg.

VIRGILIO (2014). Eneida. Madrid: C.S.I.C., colección Alma mater, tomo I. Edición de Luis Rivero

García, Juan Antonio Estévez Sola, Miryam Librán Moreno, Antonio Ramírez de Verger Jaén. 